Снежана Божанић

Филозофски факултет Универзитета у Новом Саду
УДК $726.59(497.113$ Бачки

Брестовац)“1744/2015“

\title{
ПРИЛОЗИ ЗА ИСТОРИЈУ ПРАВОСЛАВНОГ ХРАМА СВ. АПОСТОЛА ПЕТРА И ПАВЛА У БАЧКОМ БРЕСТОВЦУ $\left(\mathrm{XVIII-XX} \mathrm{BEK)^{1 }}\right.$
}

\begin{abstract}
Apstrakt: У раду се разрешавају одређена питања везана за историју православног храма посвећеног Светим апостолима Петру и Павлу у Бачком Брестовцу. Током писања монографије о православној цркви у Бачком Брестовцу дошла сам до нових сазнања која сада обелодањујем. ${ }^{2}$ Реч је о шест прилога. Први се односи на »Повељу«, односно њен препис, који је сачинио јереј Андреј Коларевић (1835). Настала је највероватније поводом освећења »жртвеника«. Оригинал из 1744. године није сачуван. Следећи прилог бави се детаљним припремама за реконструкцију и проширење храма 1778. године. Ђорђе Ракић из Нештина је на јавној аукцији 1876. добио посао израде новог иконостаса. У бачкобрестовачком храму налазе се три иконе чији аутор је академски сликар, игуман манастира Шишатовац и мученик Рафаило Момчиловић. О њима се до овог тренутка није писало, нити знало, у научним и стручним круговима. Стога, ово откриће представља новину и од нарочитог је значаја за српску културу и историју. Посебно се разматра посета епископа бачког Иринеја 1937. године нареченом храму. Благодарећи архивској грађи, анализира се црквени инвентар из 1953. године. Посебан сегмент је посвећен бачкобрестовачким зоографским иконама.
\end{abstract}

Кључне речи: црква, Андреј Коларевић, Рафаило Момчиловић

\section{А) О ПРЕПИСУ »ПОВЕЉЕ (1744) КОЈИ ЈЕ САЧИНИО ЈЕРЕЈ АНДРЕЈ КОЛАРЕВИЋ 1835. ГОДИНЕ}

Из 1734. године потичу прве сигурне вести о православној цркви у Бачком Брестовцу. Најстарија књига бачкобрестовачке парохије почела се водити 1737. године. Она је била нека врста матице: рођених, венчаних и умрлих.

\footnotetext{
1 sbozanic5@gmail.com Рад је фазни резултат пројекта Министарства за просвету и науку: Војвођански простор у контексту европске историје бр. 147002Д.

2 Божанић Снежана, Васић Жељко (2014). Храм св. айосйола Пейра и Павла у Бачком Бресӣовиу (1744-2014). Бачки Брестовац: Православна епархија бачка - Црквена Општина Бачки Брестовац.
} 
Претпоставља се да је, на месту данашњег храма, била капела настала у време формирања насеља. Реч је, највероватније, о цркви веома скромног изгледа, сиромашног инвентара, али је она задовољавала духовне потребе становништва. Први познати брестовачки свештеник био је поп Петар Поповић, који се упокојио 1747. године.

Почетак градње храма посвећеног светим апостолима Петру и Павлу прецизно се не може утврдити, али са сигурношћу се може рећи да је храм освећен 6. августа 1744. за време преосвећеног епископа бачког, сегединског и јегарског г. Висариона Павловића. Храм је дефинитивно саграђен 1743. године. Првобитна црква је била једноставна, али за то време имала је веома леп иконостас (данас у Галерији Матице српске) и неопходан богослужбени мобилијар, од којег су до данашњих дана сачувани позлаћени путир и светогорски крст. О напред написаном сведочи препис »Повеље« који је начинио јереј Андреј Коларевић (1835). Он гласи:

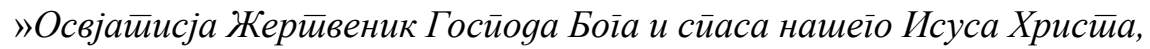
храм свјайих славних и всехвалних айостиолов Пеира и Павла, в мјасијје зовем Брестиоваи, ири иарсиивованији всјеиресвјейљејшеіо имиерайора и краља нашеїо Карла Шестиоїа; йри Преосвјашчењејшем Архијейискойије и Миироиолије Госйояине Викенииији Јовановичије, блаїословенијем же и свјашченодјестивијем Преосвјашчењејшаїо Госйоgина Висариона Павловића ирравославнаїо ейискойа бачкаїо, сеїе-

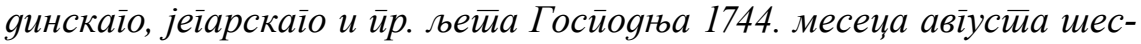
йаїо онещ.

Постоји још један препис из 1805. године, готово идентичан. Оба се чувају у олтарском делу св. храма. ${ }^{3}$ Важно је напоменути да »Повеља« није сачувана у оригану, већ у два преписа.

У вези са текстом »Повеље« за анализу се намећу одређена хронолошка неслагања. Пре свега, мора се нагласити да је Викентије Јовановић био митрополит карловачки у периоду од 1731. до 1737. године а цар Карло VI је умро 1740. године. На који начин би се онда могао образложити сам текст? Као прво, постоји могућност да је преписивач направио грешку када је транскрибовао слова у бројеве. Са друге стране, у »Повељи« се говори о освећењу »жртвеника« где се обавља проскомидија. У вези са тим, треба имати на уму и први архивски податак из 1734. године, о св. храму. Управо тада, сви актери »Повеље« су живи, те се можда у тексту »Повеље« мисли на време освећење »жртвеника«.

Архимандрит Висарион Павловић хиротонисан је 17. маја 1731. за епископа Бачког. Основао је Рождествено-богородичну школу, која је у наредном периоду била у рангу гимназије, иако тај наслов никада није понела. Од немерљивог је значаја за српску културу и духовност. Радила је и у време

Цео текст »Повеља« из 1805. године погледати: Божанић\&Васић, 2014, 10. 
када није било других српских средњих школа, након 1768. године када су затворене покрово-богородичне школе митрополита Павла Ненадовића. Био је један од најутицајнијих епископа Карловачке митрополије, којом је чак три пута администрирао - 1737. године после смрти митрополита Вићентија Јовановића, уз темишварског владику Николаја Димитријевића; 1748. године после смрти патријарха Aрсенија IV; и 1749. године после управљања Исаије Антоновића (Сава, епископ шумадијски, 1996, 33-34, 70-71, 87-88).

Све наведено сведочи да је у нареченом периоду, дакле у првој половини XVIII века, црквени живот у Бачком Брестовцу био развијен. Из тог периода потичу и имена првих свештеника у парохији. Димитрије Руварац у чланку »Бачка епархија 1724-1732« дошавши »добротом високопресвећеног г. епископа бачког Митрофана Шевића до протокола, у коју је увађено од владичанских егзарха - владике бачког Софронија Томашевића (1718-1730) и Висаријона Павловића (1731-1755)《 доноси »Села бачке епархије и имена попова од 1724-1732« (Руварац, 1911, 23-24). Под редним бројем 11 забележен је Брестовац (»село и шанац《). Поп Јаков био је свештеник, у селу, од 1724. до 1732 . године, а Јован од 1725 . године и налазио се на том месту у тренутку настанка именованог пописа (Руварац, 1911, 25). Егзарх је »прво бележио у протокол дар домаћинов, затим шта су христиани обште писали, димнице, од венчаница, попови и појединци« (Руварац, 1911, 29). Потом су свештеници били Јован Млађи Поповић (1738-1759), јереј Јаков (1738-1745), те Андреј Николић од 1740. године који је напустио место након развојачења. Средином XVIII века при храму су фугирали: Михајло Поповић, Алексеј Поповић, Јован Намесник. Ваља поменути делатност ђакона Јована (упокојио се 1750. године) и ђакона Павла.

$*$

Б) РАДОВИ НА СВ. ХРАМУ 1778. ГОДИНЕ

У последњој четвртини осамнаестог века, наметнула се потреба за проширењем постојеће цркве.

Свакако, на ову чињеницу утицао је податак о повећању броја становништва у насељу, а прикупљена су и неопходна материјална средства и грађевински материјал. Жупанији је упућена молба ради добијања грађевинске дозволе. Према нацрту, предвиђено је подизање плафонске конструкције (за $1 \mathrm{~m}$ ), доградња западног дела цркве и радови на крову који би био покривен шиндром (Andraši, 1998, 404).

Значајан податак за историју брестовачког храма, налази се у Архиву Војводине у Новом Саду. Документ, писан на латинском језику, сачуван је у оригиналу. Настао је 28. августа 1778. Представници среске власти, по одлуци Жупаније, изашли су на терен да провере да ли је све спремно за изградњу православне цркве. То су били Никола Пиуковић, срески начелник, 
и Антун Несмер (Neszmer), жупанијски јурасор. Том приликом у Бачком Брестовцу су их дочекали Михајло Берић, Алексије (Алекса) Бркић и Василије Поповић, православни свештеници. Од »сазваних људи«, пред комисију су изашли и Ђорђе Пинезић, месни нотар, и Стефан Пиља, бивши локални функционер. Припремљен је следећи материјал: 5500 цигала, 82 акова креча, 8 греда, 300 летава и 18000 ексера за шиндру. Комисија је констатовала да има и спремљеног новца. У црквеној каси се чувало 50 форинти, а на зајам је дато 125 форинти. Наведене су и димензије цркве: дужина 8,5 хвати, висина 1,5 хват, ширина 3 хвата и 3 стопе. На крају овог документа налазе се потписи представника власти који су оверени печатима (АВ, ББЖ, $1778 / 329){ }^{4}$

Главни мајстори су били дунђерин Лаза, који је за обављени посао добио 180 форинти, и зидар Јован, којем је исплаћено 156 форинти. Брзо је прикупљено, даровима парохијана, још неопходних 100 форинти. Послове је надгледао поп Алексије (Алекса), који је све ревносно бележио. Сви радови су окончани у предвиђеном року.

Извршени радови су допринели лепшем и бољем изгледу цркве. Пре свега, веома значајно је било подизање плафона јер је на тај начин она боље осветљена, а добијен је и адекватан простор за велики иконостас. Иако је био планиран наставак радова, природне и привредне (не)прилике су одложиле послове, за извесно време.

\section{$*$}

\section{В) УМЕТНИЧКИ И МАЈСТОРСКИ РАД РАФАИЛА МОМЧИЛОВИЋА И ЂОРЪА РАКИЋА}

Крајем 1876. године донета је одлука о подизању новог иконостаса. На јавној лицитацији, 8. новембра 1876. године погођен је молер из Нештина Ђорђе Ракић. Цена посла износила је 965 форинти. Том приликом уговорен је и златар Јохан Хајни из Рац (Српског) Милетића за 1300 форинти (Хроника Симе и Саве Деспотова, 1844-1913, 6). Златар и молер »наместили су 1879. иконостас у цркви« (Хроника Симе и Саве Деспотова, 1844-1913, 6).

О животу Ђорђа Ракића мало се зна. Био је родом из Нештина. Путовао је од места до места и био ангажован на осликавању више иконостаса: црква у Каћу (иконостас цркве Светог Николе (летњег) - 1861; црква је подигнута у периоду од 1840. до 1844. године), Рајевом Селу у Срему (иконостас цркве Светог великомученика Прокопија - 1887; црква је подигнута 1866. године), Пачетину у Славонији (иконостас цркве Светог оца Николаја - 1891), Визићу у Срему (иконостас цркве Светог архангела Михаила) и Лазама у Славонији

Архив Војводине у Новом Саду, Бачко-бодрошка жупанија (АВ, ББЖ). 
(ELU, 1966, 54-55). Његова дела сасвим су у складу са тадашњим уметничким и културним идејама.

Рамови на иконостатсу су позлаћени. Доминира више лепо укомпонованих и комбинованих мотива. То су: пуно цвеће, затим венци цветова и лишћа, акантусови листови и симетричне волуте. Све је вешто склопљено у целину, што доприноси импресивности иконостаса.

За храм посвећен Светим апостолима Петру и Павлу у Бачком Брестовцу 1937. године монах Рафаило Момчиловић осликао је три иконе: Богородичин трон са иконом - Боїороgииа са Христиом, Владичански трон са иконом -

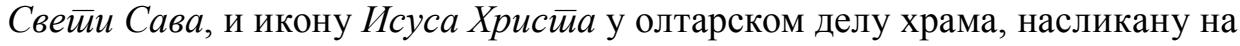
»позицији горњег места«. Све је рађено техником уља на платну.

Духовник и сликар, Ђорђе Момчиловић је рођен 23. априла 1875. у Дероњама. Био је манастирски ђак у Ковиљу. Највероватније, на њега је извршио снажан уметнички утицај Аксентије Мародић, који је радио иконостас за наречени манастир. Пошто се замонашио и показао изузетан таленат за сликање, доспео је у Српску цртачку и сликарску школу Кирила Кутлика у Београду, као питомац Архијерејског синода. Боравио је три године у сликарској школи Стагонова у Москви, а потом се обрео у Риму. Касније је постао намесник манастира Букова, а затим прешао у Ковиљ. Именован је 1932. за намесника манастира у Бођанима, а 1938. постао је игуман манастира Шишатовца. Мученички је страдао 3. септембра 1941. године (Погледати: Кашанин, 1966, 369-373; Рајчевић, 1984, 117-155).

Сликао је портрете, пејзаже и мртву природу. Бавио се црквеним сликарством. Урадио је: иконостас цркве Рођења Пресвете Богородице у Великој Крсни, иконостас манастира Раковице код Београда, иконостас и живопис цркве Св. Вазнесења Господњег у селу Соколе, иконостас цркве Св. апостола Петра и Павла у Пачиру, иконостас цркве Св. Вазнесења у Гоњем Ковиљу, иконостас цркве Ружице у Београду. Поред тога треба споменути иконе у цркви манастира Бођана, у гробљанској капели, цркви манастира Шишатовца и иконе у цркви у родном селу (Дероње).

У свим прегледима литературе, податак о његовом раду на храму у Бачком Брестовцу, остао је у потпуности непознат.

Рафаило Момчиловић је осликао Богородичин трон, техником уља на платну. На њему је представљена »Богородица са Христом«. Боїороgииа је приказана у седећем положају, на облацима. Обучена је у светлоплави хитон и мафорион црвене боје, чија је унутрашња страна љубичаста, мало усковитлана. На њеној левој руци седи мали Исус Христос, а десном га нежно придржава. Изнад њене главе је небо отворено. Мали Исус Христос је обучен у бели хитон и златни химатион. Лева рука му је спуштена и у њој држи свитак, док десном благосиља. Његова глава је мало повијена надесно и ослоњена на мајку. Богородица је нежно прислонила главу, мало улево, на Исуса Христа. Позадина је тамноплава, а у горњем делу се налази већ по- 
менуто отворено небо. У левом доњем углу налази се сигнатура: Јеромонах Р. М. 1937 (Погледати: Божанић\&Васић, 2014: 108, 109).

Икона »Светог Саве« урађена технком уља на платну, краси Владичански

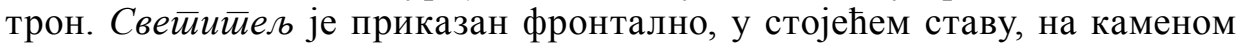
постољу. Лик светитеља представљен је са дугом брадом и брковима, и раздељком на средини главе. Обучен је у владичанску одежду, украшену извезеним крстовима плаве боје. Његова десна рука је испружена, и у њој држи јеванђеље. Позадина је тамна (Погледати: Божанић\&Васић, 2014: 110, 111).

»Икона Исуса Христа« налази се у олтарском делу св. храма, на »позицији горњег места«. Урађена је техником уља на платну. Исус Христ је приказан у седећем положају, са раширеним рукама. Крај његове леве и десне ноге осликан је по један анђео. У доњем десном углу налазе се иницијали: Јеромонах Р. М. 1937 (Погледати: Божанић\&Васић, 2014: 55, 110).

На основу архивских података о ангажовању, карактеристичних иницијала академског сликара и монаха и упоређивањем његових радова, са сигурношћу се може закључити да су наречене иконе дело сликара, монаха и мученика Рафаила Момчиловића.

Г) ПОСЕТА ЕПИСКОПА БАЧКОГ ИРИНЕЈА 1937. ГОДИНЕ БАЧКОБРЕСТОВАЧКОМ ХРАМУ

Опсежне припреме за генералну оправку св. храма вршене су 1936. године.

Већ 1937. године погођени су следећи мајстори и стручњаци (Летопис парохије Бачки Брестовац, св. 1, 16):

- столар Сретен Шиђански из Сомбора (столарски радови за 12000 динара),

- зидар и лимар Фрања Хашел (цена за зидарске и лимарске послове износила је 46650 динара),

- бравар Лазар Лазић (цена 12990 динара),

- јеромонах Рафаило из Бођана за чишћење икона (по цени од 4500 динара),

- академски сликар Лазар Николић из Куле је ангажован за декоративно-сликарски рад, чишћење иконостаса и позлата (цена 12000 динара).

У августу 1937. је уговорено увођење електричног светла са Николајем Ентеригом за цену од 13 динара по дужном метру. Наречене године, св. храм је интензивно поправљан и рестауриран.

Његово преосвештенство епископ бачки господин Иринеј је 12. новембра 1937. осветио обновљени храм Св. Петра и Павла у Бачком Брестовцу. Тим 
поводом издата је »Повеља«. Текст је својеручно унео и потписао епископ новосадско-бачки Иринеј у Летопис парохије Бачки Брестовац (Летопис парохије Бачки Брестовац, св. 1, 19; (Божанић\&Васић, 2014: 33). Њен садржај доносимо у целини:

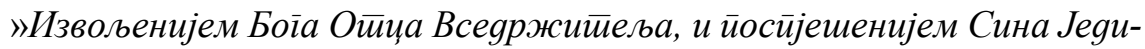
нороднаїо, и совершенијем всейресјайаїо Духа обновисја сеј храм свјайих славних и всехвалних и иервоверховних айостиол Петира и Павла и освјайисја свјашченодејстивијем сербскайо йравославнаїо ейискойа: новосаяско-бачкаїо, сомборскаїо, сеїеgинскаїо и јеїарскекаі̄o йреосвјашчењејшаі̄o Госйоgина Иринеја, иири блаїовјерном краљи Јуїославије Пеитрје Вйором во веси Бачком Бресииовије, в љейо ой рожяесивва Боїа Слава 1937 мјесјача новембрија 12 gне.

У потпису:

Горе помјанушиј смирениј

Иринеј,

Епископ новосадско-бачки«

\section{Д) ЦРКВЕНИ ИНВЕНТАР ИЗ 1953. ГОДИНЕ}

Захваљујући Зайисницима сеgнииа ирквено-ойшииинске уйраве оg 21. jaнуара 1940. іоoине gо 25. gецембра 1955. іолине који се чувају у Архиви храма Св. Апостола Петра и Павла у Бачком Брестовцу, прецизно се може реконструисати црквени инвентар из 1953. године.

Када је јереј Константин Јорговић 31. августа 1953. разрешен дужности пароха бачко-брестовачког, пописан је инвентар и извршена његова предаја Управи парохије.

Дана 10. септембра 1953. црквени инвентар састојао се од: црквених књига (51), две дарохранилнице, једног прибора за пришеће болних, два путира, два дискоса, једне кашикице, једног прибора за крштење, једне петохлебнице, ђачких стихара (21), два пешкира, шест покривача за наслон, два свештеничка стихара, пет ћилима, једне плаштанице, икона за целивање (21), два антиминса, три ручна крста, два дрвена распећа на трпези, шест дрвених чирака, четири рипида (рипиде), једног крста, ножа за сечење поскурица, пет светњака од гвожђа, два светњака од месинга, једне кадионице, две сасуде, два чирака за децу, једног прибора за вино са тајном, шест кандила, једног наслона за целивање, четири барјака, једне литије, два полијелеја, пет одежди, један Христов гроб, четири рипиде за сахрану, два крста, један туторски орман, тридесет разних икона, једне завесе за двери, једне чиније за водоосвећење и две клупе.

Том приликом, у присуству архијерејског намесника сомборског Слободана Увалића, Управи парохије предато је још: 
- три књиге протокола крштених (1896/935, 1935/949 и од 1949. године),

- две књиге протокола венчаних (од 1896/935 и од 1935. године),

- две књиге протокола умрлих (од 1896/935 и од 1935. године),

- две књиге домовних протокола,

- једна књига навештења,

- једна књига записних о предбрачним испитима,

- једна књига парохијског Летописа,

- једна књига исповеђених и причешћених,

- две књиге деловодних протокола,

- осам књига циркуларних протокола,

- једна стара књига исповеђених и причешћених,

- Службени лист од 1927. године до тада (непотпун),

- два штембиља и мастионица.

Од намештаја уписани су: један орман за архиву, сто и седам столица. За администраторе парохије постављени су стапарски пароси: протојереј Иван Поповић и јереј Стеван Опанчарев.

\section{Ђ) ЗООГРАФСКЕ ИКОНЕ}

Иконе из Бачког Брестовца које се чувају у Галерији Матице српске рађене су техником уље на дасци и темпера на дасци. Највећи број аутора је непознат. За неке је на основу стручних анализа утврђено да су их радили руски или српски сликари. Григорије Јездимировић је аутор неколицине икона, док одређен број припада кругу Димитрија Бачевића.

Бачкобрестовачке зоографске иконе настале почетком XVIII века дело су, у највећем броју, непознатих аутора (Lazić, 1998, 407). Сликари-зоографи били су народни уметници, скромног образовања и могућности.

Против необразованих и неуких сликара, иступио је после сеобе патријарх Арсеније IV Јовановић Шакабента. Циркуларом од 5. јула 1743. Забрањује се »куповина икона од којекаквих молера«, а онима који »осећају вољу и дар за моловање«, односно имају талента за сликање, препоручује се да дођу у Сремске Карловце, код »Руса Јова«, искусног иконописца, и образују се (Руварац, 1911, 27-31).

»Рус Јов« је украјински иконописац Јов Василијевич (Василијевић), о чијем се животу мало зна. У сваком случају, значајан је његов утицај на развој српског барокног сликарства (Микић\&Шелмић, 1981, 19-24). Његовој групи припадали су Васа Остојић, Никола Нешковић, Јанко Халкозовић и иконописци непознатог имена из Срема (Микић\& Шелмић, 1981, 79-87).

У периоду од двадесетих до седамдесетих година XVIII века, веома значајно је интензивирање руско-српских веза, које су биле вишеструке. Остављајући по страни политичке контакте, културне и духовне везе између 
Русије и Карловачке митрополије су успостављане на најразличитије начине.

Теологија, реторика, филозофија, сликарство и архитектура су изучавани на Кијевско-могиљанском колегијуму, који од 1718. године прераста у академију. Више младих људи са наших простора боравило је у Кијеву, изучавајући, измећу осталог, и сликарство (Шелмић, 2004, 81).

»За развој и барокизацију српске уметности« важни су руски сликари који су били ангажовани на нашој територији (Јовановић, 1963, 390). У нареченом периоду, то су пре свега, Григорије Герасимов, поменути Јов Василијевич и Василије Романович „од Мале Русије“ (Давидов, 1969, 119-137).

Димитрије Бачевић припада »сликарима раног барока«, односно »прелазном периоду« (Погледати: Петровић\&Кашанин, 1927, 84-85; Микић\&Шелмић, 1981, 11-19; Шелмић, 2004, 41). Сликарство је усавршио у Кијево-печерској лаври. Бачевићев стил карактерише обилна употреба злата у виду декоративне орнаментике и реализам осликаних фигура. Његова дела су: иконостас капеле на Доброј води у Даљу; иконостас Горње цркве у Сремским Карловцима; иконостас Николајевске цркве у Земуну, заједно са Василијем Остојићем; иконостас Сретењске цркве у селу Крушедолу, са Теодором Димитријевићем Крачуном; иконостас цркве манастира Беочина, са Т. Крачуном; иконостас српске цркве у Прхову; иконостас цркве манастира Новог Јаска (1769); престоне иконе за српске цркве у Голубинцима; иконе за цркву манастира Шишатовца; престоне иконе за цркву манастира Старог Јаска; иконе за цркву манастира Бешенова. Радио је са Димитријем Поповићем и Теодором Крачуном, а за његове следбенике сматрају се Николај Петровић, Аксентије Остојић и по одређеним стилским карактеристикама Глигорије Давидовић Обшић. Неколицина бачкобрестовачких икона рад је непознатих аутора, који су припадали његовом уметничком кругу.

Григорије Јездимировић, родом из Борова, представник је високог барока. Био је сликар и позлатар. Живео је у другој половини XVIII и почетком XIX века. Радио је: иконостас цркве Св. Јована Крститеља у Бачкој Паланци; иконостас цркве Светог Димитрија у Даљу са Павлом Ђурковићем и бројне целивајуће иконе. То је период културне оријентације ка Бечу. За цркву у Бачком Брестовцу урадио је следеће иконе: Св. Никола, Пророк Јона и Пророк Јелисеј.

На трећој седници Привременог поверенства Црквене општине у Бачком Брестовцу, одржаној 12. јуна 1955. године, донета је одлука да се »старе иконе« продају Матици српској »за 316000 динара«, а новац употреби за оправку цркве (Заиичсник сеgнииа ирквено-оимииинске уйраве оg 21. јануара 1940. іо gине gо 25. gецембра 1955. іоgине, погледати Дневни ред са треће редовне седнице Привременог поверенства Црквене општине, одржане 12. јун 1955). Укупно 18 икона је продато Галерији Матице српске 1955. године, a 11 је дато на рестаурацију и конзервацију. 
У Галерији Матице српске налази се 18 икона из Бачког Брестовца:

- Богородица (део деизиса), непознат аутор, уље на дасци

- Богородица са Христом, непознат аутор, уље на дасци

- Богородица са Христом, непознат аутор, уље на дасци

- Богородица са Христом, непознат аутор (круг Димитрија Бачевића), уље на дасци

- Богородица са Христом, непознат руски аутор, уље на дасци

- Васкрсење Христово, непознат руски аутор, уље на дасци

- Исус Христос, непознат аутор (круг Димитрија Бачевића), уље на дасци

- Непозната светитељка, непознат аутор, уље на дасци

- Непозната светитељка, непознат аутор, уље на дасци

- Непозната светитељка, непознат аутор, уље на дасци

- Пророк Јелисеј, аутор Григорије Јездимировић, уље на дасци

- Пророк Јона, аутор Григорије Јездимировић, уље на дасци

- Св. архиђакон Стефан, непознат аутор, уље на дасци

- Св. Јован, непознат аутор (круг Димитрија Бачевића), уље на дасци

- Св. Максим, деспот српски, непознат аутор, уље на дасци

- Св. Никола, аутор Григорије Јездимировић, уље на дасци

- Св. Никола, непознат аутор, уље на дасци

- Св. Никола, непознат аутор (круг Димитрија Бачевића), уље на дасци

- Уз реверс, чува се у Галерији Матице српске у Новом Саду 11 икона:

- Св. апостоли Петар и Павле, непознат аутор, темпера на дасци, уз реверс

- Св. апостоли Петар и Павле, непознат аутор, темпера на дасци, уз реверс

- Васкрсење Христово, непознат аутор, темпера на дасци, уз реверс

- Св. архангел Михаило, непознат аутор, темпера на дасци, уз реверс

- Св. Григорије, непознат аутор, темпера на дасци, уз реверс

- Св. Димитрије, непознат аутор, темпера на дасци, уз реверс

- Св. Киријак, Опшелник, непознат аутор, темпера на дасци, уз реверс

- Св. Кузман и Дамјан, непознат аутор, темпера на дасци, уз реверс

- Св. Јован Богослов, непознат аутор, темпера на дасци, уз реверс

- Св. Параскева, непознат аутор, темпера на дасци, уз реверс

- Св. Симеон Богопримац, непознат аутор, темпера на дасци, уз реверс

Данас се у самом св. храму, и поред свега, налази велики број икона, од којих су неке веома старе. Прилозима парохијана, последњих година, њихов број је знатно увећан. 


\section{ИЗВОРИ И ЛИТЕРАТУРА:}

Andraši, Olga (1998). Prvih pola stoleća bačkobrestovačke pravoslavne crkve Sv. Apostola Petra i Pavla. U: Marjanović Miloš, Manojlović Dimovska Jelena, \& Lazić Lazar (ured.) (1998). Seoske i slašarske crkve u Vojvodini. Edicija Kulturno-istorijska baština Vojvodine XIV (str. 402-404). Novi Sad: Kulturno-istorijsko društvo PČESA.

Архив Војводине у Новом Саду, Бачко-бодрошка жупанија. (АВ, ББЖ).

Божанић Снежана, Васић Жељко (2014). Храм св. айосйола Пейра и Павла у Бачком Брестиовиу (1744-2014). Бачки Брестовац: Православна епархија бачка - Црквена Општина Бачки Брестовац.

Давидов, Динко (1969). Украјински утицаји на српску уметност средине XVIII века и

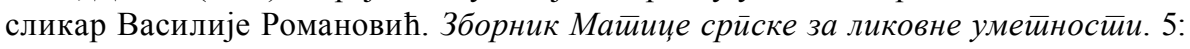
119-137.

Enciklopedija likovnih umjetnosti 4 (1966). Zagreb: Jugoslavenski leksikografski zavod.

Јовановић, Миодраг (1963). Руско-српске уметничке везе у XVIII веку. Зборник Филозофской факулиетей у Беоїраgу. VII-1: 379-411.

Кашанин, Милан (1966). О Рафаилу Момчиловићу. Зборник Майице срӣске за ликовне умейностии. 2: 369-373.

Lazić, Milisav (1998). Ikone bačkobrestovačke pravoslavne crkve Sv. Apostola Petra i Pavla. U: Marjanović Miloš, Manojlović Dimovska Jelena, \& Lazić Lazar (ured.) (1998). Seoske i slašarske crkve u Vojvodini. Edicija Kulturno-istorijska baština Vojvodine XIV (str. 405-411). Novi Sad: Kulturno-istorijsko društvo PČESA.

Летиойис йарохије Бачки Брестиоваи og 1955. gо 1967. йоgине. Св. 1. Архив храма Св. апостола Петра и Павла у Бачком Брестовцу.

Микић Олга, Шелмић Лепосава (1981). Мајстиори йрелазної йериоgа срӣской сликарсиива XVIII века. Нови Сад: Галерија Матице српске.

Петровић Вељко, Кашанин Милан (1927). Срйска уметиности у Војвоgини. Нови Сад: Матица српска.

Рајчевић, Угљеша (1988). Рафаило (Георіије) Момчиловић, монах, сликар и мученик (1875-1941). Београд: Итака.

Рајчевић. Угљеша (1984). Рафаило Момчиловић (1875-1941). Зборник Майице срӣске за ликовне умеитностии. 20: 117-155.

Руварац, Димитрије (1911a). Бачка епархија 1724-1732. Архив за истиорију срйске йравославне карловачке мийройолије. I: 23-31.

Руварац, Димитрије (1911б) Циркулар йайријарха Арсенија Јовановића о свейковаюу иразника и о забрани куйовања икона оg којекаквих молера и ко осећа вољу и gар за моловање, gа gође у Карловие Русу Јову и gа калуђери не ияу без дозволе насйојаиельсивва йо селима. Богословски гласник. ХХ: 27-31.

Сава, епископ шумадијски (1996). Срйски јерарси оg gевейої gо gваgесейой века. Београд, Подгорица, \& Крагујевац: EVRO, UNIREKS, \& KALENIĆ.

Хроника Симе и Саве Десйойова (1844-1913). Рукопис унет у Лейойис йарохије Бачки Брестиоваи. Свеска 1. Архив храма Св Апостола Петра и Павла у Бачком Брестовцу. Шелмић, Лепосава (2004). Срйско зияно сликарсйво XVIII века. Нови Сад: Галерија Матице српске. 


\title{
CONTRIBUTIONS TO THE HISTORY OF THE ORTHODOX CHURCH ST. APOSTLES PETER AND PAUL IN BAČKI BRESTOVAC (XVIII-XX CENTURY)
}

\begin{abstract}
SUMMARY
The paper presents some unknown and lesser known informations related to the history of the temple in Bački Brestovac. During the consecration (1744), the charter was issued that was not kept in the original. The transcript of 1835 which contains certain historical errors is analzyed. They are carefully reviewed and possible solutions are given. An important fact for the history of temple Bački Brestovac, is located in the Archive of Vojvodina in Novi Sad. The document, written in Latin, is preserved in the original. It was created on 28 August 1778. It contains important information about the material and financial resources collected for this project. In late 1876, a decision was made to raise the new iconostasis. At the public auction, on 8 November 1876, the project was given to Đorđe Rakić from Neštin. For the temple dedicated to the Holy Apostles Peter and Paul in Bački Brestovac, in 1937 the monk Rafail Momčilovic has painted the Bishop throne - St. Sava, Virgin's throne - Madonna and Christ, and the icon of Jesus Christ in the altar area of St. Temple, in the "position of the upper place." Everything was done in oil on canvas. These data, up until now, were not known to the general scientific and professional public.
\end{abstract}

